\title{
Classifiers in Lao: A Cognitive Linguistic Approach
}

\author{
Rattanapraxa Analee and Nuntana Wongthai
}

\begin{abstract}
This research is aimed at studying classifiers in Lao and the cognitive process of Lao native speakers reflected by their usage of classifiers. The scope of the study is limited to classifiers in standard Lao (Vientiane dialect). The total number of informants involved in the study is 90. The researchers analyze the attributes of prototypical nouns and non-prototypical nouns to highlight the relationship between them. The analysis is based on the prototype theory, attributes in categorization and idealized cognitive models (ICMs). The results indicate that the Lao classifier system works on some kinds of general principles like in earlier studies by Dyirbal and Thai. However, the study shows that the cognitive system of Lao people is influenced by their own geographic and cultural factors as well as their religious beliefs. The study also shows the cognitive system of Lao people which is different from others, even in Thai, which is the member of the same language family (Tai-Kadai).
\end{abstract}

Index Terms-Classifiers in Lao, cognitive linguistic approach, prototype theory.

\section{INTRODUCTION}

The basic function of classifiers is to build up a descriptive referring expression for the noun [1]. Lao is one of languages with numeral classifiers. For these languages, nouns are not inflected for plural and cannot be enumerated directly, but require a classifier to accompany the quantifier, for example

$\begin{array}{lll}\begin{array}{l}\text { Noun } \\ \text { k'án hōm } \\ \text { 'three umbrellas' }\end{array} & \begin{array}{l}\text { Numeral } \\ \text { sam }\end{array} & \begin{array}{l}\text { Classifier } \\ \mathrm{k}^{\mathrm{h}} \text { an }\end{array} \\ & & \end{array}$

The position of classifier in Lao follows number, for example:

$\begin{array}{lll}\text { (1) } \begin{array}{l}\text { Noun } \\ \text { house } \\ \text { two houses } \\ \text { egg }\end{array} & \begin{array}{l}\text { Numeral } \\ \text { two }\end{array} & \begin{array}{l}\text { Classifier } \\ \text { lan }\end{array} \\ \text { two eggs } & \text { two } & \text { nua:j }\end{array}$

The classifier is an important aspect of grammar in Asian languages, such as Thai, Lao, Vietnamese, Chinese, Japanese and Korean. It can determine the meaning of homonyms, for example “эๆ”/ká/ 'kettle' and "ๆๆ”/ká/ 'crows' as in example (3) and (4).
(3) ká
sŏy
two
nua:j
kettle

\author{
'two kettles'
(4) ká sŏy
crow two
'two crows'

to:

Example (3) /nua:j/ is the classifier used with the noun /ká/ 'kettle' and example (4) /to:/ is the classifier used with the noun “эๆ”/ká// 'crow'.

Furthermore, the classifier can be used to classify objects or concepts, for example the classifier "ข่อย" /nua:j/ is used with nouns which have round shape such as a ball, an orange, an egg. The classifier "ใบ"/baj/ is used with nouns which have round and flat shape such as a leaf, a tray. The classifier "เสั้บ" /sên/ is used with nouns which have small string shape, such as hair, a wire, a thread.

Phumee Vongvichit, linguist [2], a Lao said that the classifier is used with nouns according to the characters of noun. The classifier "ข๊อย"/nua:j/ is used with, "थู" /phú:/

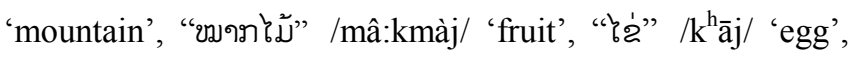
“ขมอท”/mûa:k/ 'hat', “ขับไข” /kápfáj/ 'book of matches',

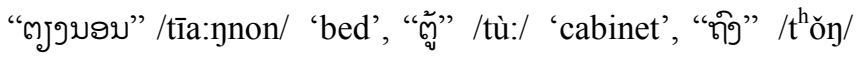
‘bag, " ‘๓ะ”/tó/ 'table', “โมg”/mó:y/ 'watch', as in example (5)-(7)

\begin{tabular}{|c|c|c|c|}
\hline \multirow[t]{2}{*}{$(5)$} & $k^{h} \bar{a} j$ & sว̆y & nua:j \\
\hline & egg & two & $\mathrm{CL}$ \\
\hline & 'two eggs' & & \\
\hline \multirow[t]{3}{*}{ (6) } & phú: & sว̆y & nua:j \\
\hline & mountain & two & $\mathrm{CL}$ \\
\hline & 'two mountains' & & \\
\hline \multirow[t]{2}{*}{ (7) } & mûa:k & sǒn & nua:j \\
\hline & hat & two & $\mathrm{CL}$ \\
\hline
\end{tabular}

The classifier “ลๆๆ”/lám/ with is used “ยิy”/nón/ 'plane',

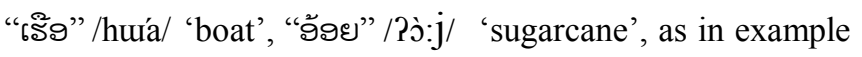
(8)-(10)

Manuscript received August 19, 2014; revised January 20, 2015,

Rattanapraxa Analee is with the Srinakharinwirot University, Thailand (e-mail: bank200s@hotmail.com).

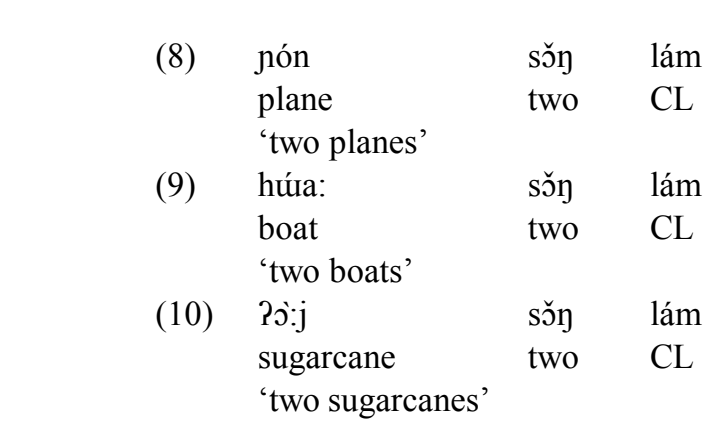

The classifier “ถับ” / $\mathrm{k}^{\mathrm{h}}$ á:n/ is used with “ลิด” /lōt/ 'car', 
“ลิคฤิบ”/lōt t 1̂̀:p/ 'bicycle', “ลิคจัท”/lōt tcák/ 'motorcycle’, “ถับธิ่ป” /k án hōm/ 'umbrella', as in example (11)-(13).

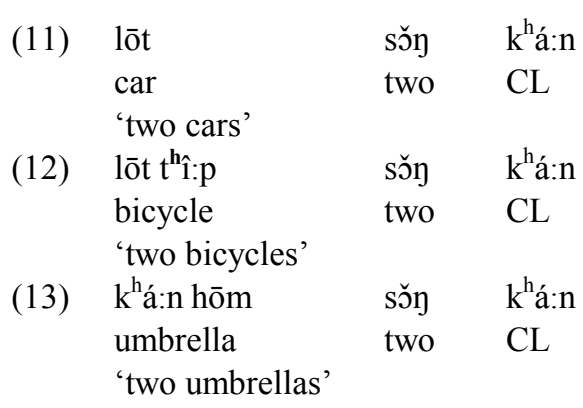

Notice the above examples, it is interesting that one classifier can be used with many types of nouns. The classifier “ลํ" /lám/ uses with a watercraft noun, such as "ธฮ๊९"/húa:/ 'boat', an aerial vehicle, such as “ยิบ”/nón/ 'plane', but it can also use with a plant noun like "פ้อย”/ /ว่:j/ 'sugarcane' and "ไม้ไต่" /màj p $\mathrm{h}^{\mathrm{h}} \mathrm{j} /$ 'bamboo'.

A classifier "ถับ” $/ \mathrm{k}^{\mathrm{h}}$ á:n/ can use with vehicle noun like, “ล์ด”/lōt/ “car' “ล์ถจัภ” /lōt tcák/ (motorcycle) “ล์ถฤิบ”/lōt thî:p/ 'bicycle' and object nouns, like “ถับฮิ่d” / $\mathrm{k}^{\mathrm{h}}$ á:n hōm/ 'umbrella'

The paper is aimed to study classifiers in Lao and to examine the reasons why one classifier can be used with many types of nouns as well as to analyze the cognitive process of Lao native speakers reflected by their usage of classifiers. The analysis is based on the prototype theory [3], attributes in categorization [4] and idealized cognitive models (ICMs) [5].

\section{RESEARCH METHODOLOGY}

The research methodology is divided into 4 steps as follows.

1) The collection of nouns in Lao from 4 dictionaries:

- Lao Dictionary [6].

- The Lao picture of Dictionary [7].

- Lao-Thai-English Dictionary [8].

- Lao-Thai Dictionary [9].

For this step, the researcher gained 540 nouns from those dictionaries.

2) The elicitation of classifiers Lao native speakers used with nouns collected in the first step. This step is processed by using a questionnaire. The example of questionnaire used to elicit classifiers used with each noun is in Appendix A.

There are 10 informants participating in this step. The qualification of informants is as follows:

- Lao nationality;

- Lao native speakers;

- Age between 15-60 years old;

- Graduated at least at elementary school;

- Born in Vientiane and vicinity of Lao PDR.

For this step it found 65 classifiers.

3) The elicitation of the first nouns that come to the informants' minds when they got the stimulus, a given classifier.
In this step is processed by using a questionnaire. (see appendix B)

There are 40 informants participating in this step and they are divided into 20 females and 20 males. The qualifications of informants are as follows:

- Lao nationality;

- Lao native speakers;

- Age 12-60 years old;

- Born in Vientiane and vicinity of Lao PDR;

Table 1 shows the qualifications of informants in step 3.

TABLE I: THE QUALIFICATIONS OF INFORMANTS IN STEP 3

\begin{tabular}{l|l|c|c}
\hline \hline \multirow{2}{*}{ Gender } & Education /occupation & Age & Number \\
\hline \hline \multirow{3}{*}{ Male } & Elementary school & $12-14$ & 5 \\
& High school & $15-18$ & 5 \\
& University (undergraduate) & $19-25$ & 5 \\
& Worker & $26-60$ & 5 \\
\hline \multirow{4}{*}{ Female } & Elementary school & $12-14$ & 5 \\
& High school & $15-18$ & 5 \\
& University (undergraduate) & $19-25$ & 5 \\
& Worker & $26-60$ & 5 \\
\hline \hline
\end{tabular}

4) 2.4 The elicitation of prototypical nouns and nonprototypical nouns used with each classifier.

The fourth step is carried out by asking the informants to rate how good and poor each noun of each classifier is. The informants were asked to put the number in the questionnaire (see Appendix C). Number 1 represents the best noun or prototypical noun and the nouns rated in the following numbers are non-prototypical nouns. In this step there are 40 informants with the same qualifications as in step 3

The prototypical nouns used with classifiers in Lao.

\begin{tabular}{|c|c|c|}
\hline & Classifiers & Prototypical nouns \\
\hline 1 & “ถับ” /k á:n/ & “ลิด” /lōt/ 'car' \\
\hline 2 & “ท้อบ” /kò:n / & “ภ้อบข๊ม” /kò:n:hǐ:n:/ 'rock' \\
\hline 3 & “ด้ๆ山 /dà:m/ & $\begin{array}{l}\text { “ด้ๆบข้ๆ” /dà:m p p⿳à/ 'handle' } \\
\text { (for machetes) }\end{array}$ \\
\hline 4 & “๘ปัด” /mēt/ & 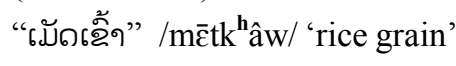 \\
\hline 5 & “ฝัท" /fãk/ & $\begin{array}{l}\text { “ฆม่าฤิ่ว”/mâ:kt"ūa:/ } \\
\text { ‘long bean' }\end{array}$ \\
\hline 6 & 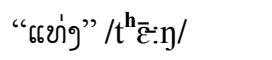 & “อๆ” /k à:m/ 'bullion' \\
\hline 7 & “ฑะบ9ท” /kábô:k/ & 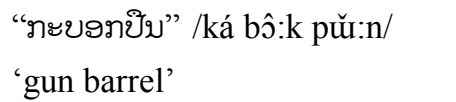 \\
\hline 8 & “ฑั้” /kj:/ & $\begin{array}{l}\text { “ภั้เจ้ย" /kj:tcìa:/ 'roll' } \\
\text { (for toilet paper) }\end{array}$ \\
\hline 9 & “แท้อ” /kغ่w/ & $\begin{array}{l}\text { “แภ้อยๆ”/kغ̇:wja:/ 'bottle' } \\
\text { (for medicine) }\end{array}$ \\
\hline 10 & “ขั้g”/bày/ & $\begin{array}{l}\text { “ขั้gไข" /bànfáj/ } \\
\text { 'Bang-fai rocket' }\end{array}$ \\
\hline 11 & “คอ9”/dǔa:y/ & “ดๆอ” /da:w/ 'star' \\
\hline
\end{tabular}


Classifiers

12

"โ๓"/to:/

13

14

“ลๆ” /lám/

15

“ขึอ" /hǔa:/

“ข่อย" /nua:j/

16

"ธัๆ”/há:y/

17

“ดงク”/dô:k/

18

19

20

21

22

23

24

25

26

27

28

29

30

31

32
Prototypical nouns

“สัด” /sát/ 'animal'

“เธ๊ฮ”/huá:/ 'boat'

“ฑะขาล่่ปิ” /kálámpi:/ 'cabbage'

“ڤุ” /k $/ \mathrm{k}^{\mathrm{h}} /$ 'bucket'

“ธัวมิ๊” /há:Đnōk/ 'bird nest'

“ดงทไป้” /dô:kmàj/ 'flower'

“สัั้บขึ่”, /sênmì:/ 'vermicelli'

“ขูอถไข” /lô:t fáj/

'fluorescent lamp'

“จิธขมาย” /t6ó:t mă:j/ 'letter'

"สายมจั้ฉ99" /să:jnàmk oy/

'Mekhong river'

"โธวรృบ”/hó:y hía:n/ 'school'

“เทิข” /kว̂p/ 'shoes'

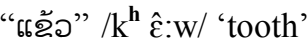

"ฉ99บุบ" /so:ybun/ " merit

enverlope'

“แ๗ข” /hع̌:/ 'fishnet'

“ติ้บไม้" /tônmàj/ 'tree'

“ใขไป้” /bajmàj/ 'leaf'

“ปะฑู"/pá:tu:/ 'door'

“ฑะป่งgิิ山” /ká: p̄̄:n nóm/

‘tin' (for milk)

“"ข”"/p $\mathbf{h}_{\grave{\varepsilon}}$ :/ 'cloth'

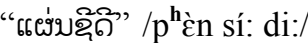

'compact disc' (CD)

“รับไข”/kápfáj/ 'book'

(for matches)

“แขาอบ” /wع̌:n/ 'ring'

“ท992าย” /ko:ysá:j/ ‘pile’

(for sand)

“ไม้ขับขัด” /màjbant ${ }^{\mathrm{h}} \overline{\mathrm{a}}$ /

'ruler'

“เธ๊จบ” /húa:n/ 'house'

“ข่่ไป้”/nǒ: mă:j/

'bamboo shoot'

“ปๆท" /pâ:k/ 'mouth'

“ลิคฉะบอบ” /lōtk ábua:n/

'truck' (trucks run long line)

"gำ่'”/knǒ: $p^{\mathbf{h}} \overline{\mathrm{j}} \mathrm{j} /$

'bamboo clump'

“ธอๆเฉิ้ๆ”/húa:yk âw/ 'spike'

“ส”/sว̌:/ 'pencil'

"ธัขบ" /hà:n/ 'hut'

(hut on the tree)

“ของคงทไป้”/phúa:ndô:kmàj/ 'garlands'

“เสิๆเธ๊ฮม” /sǎwhúa:n/

'pillar' (for house)

"ฝูgเปัด” /fú:npét/ 'herd'

(for ducks)

“ขู"/hǔ:/ 'ear'

“ฉอคมิ山” /k ût:tnóm/

'bottle' (for milk)

“ลิบ” /lip/ 'lift'

“こิอ” /k ǔa:/ 'bridge’

“อิบ” /k on/ 'human'

“ขะ” /p $\mathrm{h} \overline{\mathrm{a}} /$ 'monk'

“จิอ"/t6ua:/ 'novice'

“ป้ๆย”/pâ:j/ 'sign'

“เอิ้าปุ้บ” /k âwpùn/

'Lao vermicelli'

“อั้บได” /k ândaj/ 'ladder'

"ตุรบขั้" /tuknà:m/

'plastic bottles' (for water)

"ทงภยๆ”/kô:kja:/ 'cigarette'

"ฉ้าๆจ้รด”/sà:ylìa:y/

'elephant' (feeding elephants)

“ฉ้ๆๆ”/sà:y/ 'elephant'

(wild elephants)

“ฆมาภสาล๊” /mâ:ksă:lí:/ 'corn'

“แฉบ”/k غ̇̀n/ 'arm'

“2ๆ”/k $\mathrm{k}$ ă:/ 'leg'

“บิ้อ”/níw/ 'finger'

The cognitive system of Lao people reflected by the usage of classifiers, according to [5]

1) Propositional Models specify element, their properties, and the relations holding among them. Much of our knowledge structure is in the form of propositional models. Thus, a model of a domain (like fighting in Dyirbal) would include elements that occur in that domain (like fighting spears). A propositional model characterizing our knowledge about fire would include the fact that fire is dangerous. A taxonomic model, like the base model for Dyirbal given above, would include four elements corresponding to each of the categories, and a condition stating that anything not a member of the first three categories is in the fourth.

2) Image-schematic Models specify schematic images, such as trajectories or long, thin shape or containers. Our knowledge about baseball pitches includes a trajectory schema. Our knowledge about candles includes a long, thin object schema.

3) Metaphoric Models are mapping from a propositional or image-schematic model in one domain to a corresponding structure in another domain. The CONDUIT metaphor for communication maps our 
The table shows that the idealized cognitive models reflected by the use of classifier of Lao people are image-schematic model, propositional model and metonymic model. The classifier system in Lao works on the image-schematic model the most. This may reveal that Lao people mostly refer to schematic images of objects when they use language especially classifiers.

\section{CONCLUSION}

The study shows that the cognitive system of Lao people is influenced by their own geographic factor shown in "สาย" /să:j/, which is used with the prototypical noun "มั้ๆ2งg" /nà:mk ${ }^{\mathrm{h}} \mathrm{oy} /$ 'Mekong river'. It is because the Mekong River is the main river that feeds Lao people since ancient times. Classifiers in Lao also reflect their religious beliefs as in "ติบ" /ton/ which is used with the noun "จิอ" /tcua:/ 'novice' which is different from “wะ” $/ \mathrm{p}^{\mathrm{h}} \overline{\mathrm{a}} /$ 'monk'. (Even though novices also observe the religious precepts but they observe less precepts than monks do so Lao people use different classifiers). The study also shows that the classifier system in Lao is similar to Thai's [10]. Even though these two countries are adjacent and their languages are the members of the same language family (Tai-Kadai), there are some differences in their classifier system. For example, metaphorical model is not found in Lao. It may reveal that Lao people do not map one domain of experience onto another in their classifier system. They mostly perceive things by images. Moreover, they uses different idealized cognitive model for the same classifier. Take the classifier/duay/ as an example. Thai people use this classifier with nouns like sun, moon, star because they located in the sky. Therefore the propositional model underlies the usage of this classifier for Thai. While it is image schematic model which underlie the cognitive system of Lao when using this classifier.

\section{APPENDIX A: EXAMPLE OF QUESTIONNAIRE} แบบสงบฤๆมผู้ของขาสาฉาอลๆอ

\begin{tabular}{|c|c|c|}
\hline 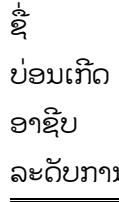 & ฮายุ & ปิ เขถ \\
\hline ลำถับ & ถๆบๆมขๆสๆลๆอ & ถํลัรสะบะบๆม \\
\hline 1 & ภาบั้ๆ & \\
\hline 2 & ตัดฮั้ & \\
\hline 3 & ข้ๆ & \\
\hline 4 & ร้องท่ายฐูบ & \\
\hline 5 & ถำ & \\
\hline 6 & ม้ๆบั่ว & \\
\hline 7 & ขะยๆบๆบ & \\
\hline 8 & ยิม & \\
\hline 9 & แมอ & \\
\hline
\end{tabular}

\begin{tabular}{ll}
10 & $\begin{array}{l}\text { ขมาระอบ } \\
11 \\
\text { เกิบ }\end{array}$ \\
540 & 2อถบิม \\
\hline
\end{tabular}

APPENDIX B: EXAMPLE OF QUESTIONNAIRE

แบบสงบฤๆมผู้บราขๆสาฉๆอลๆอ

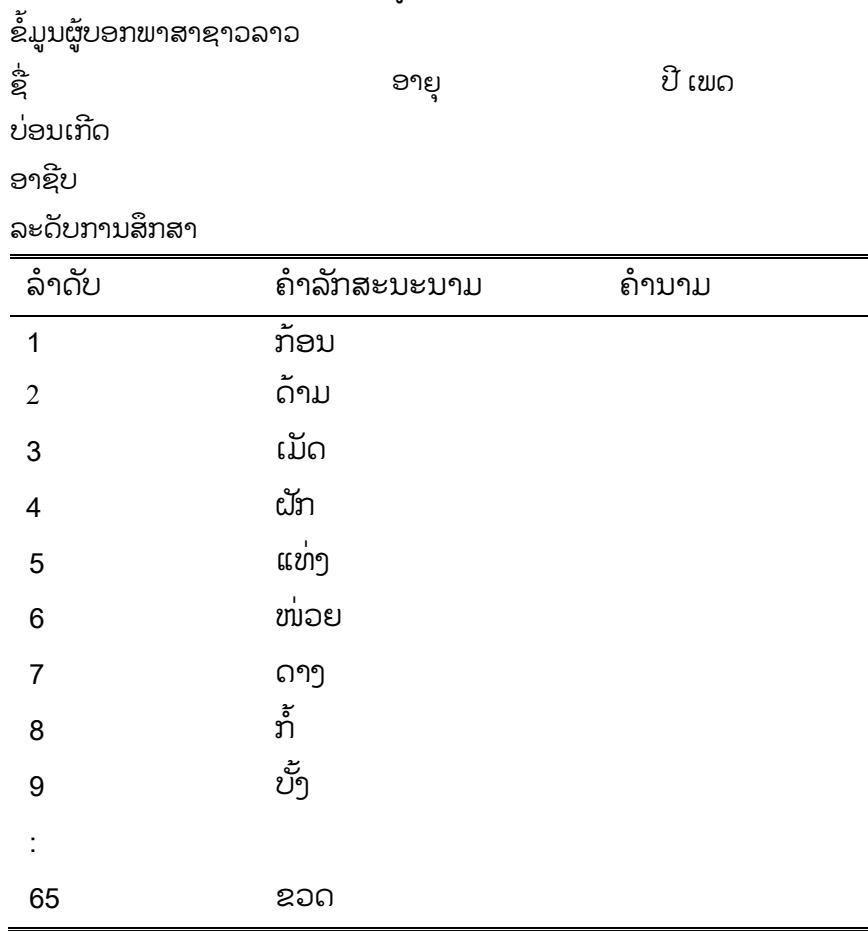

\section{APPENDIX C: EXAMPLE OF QUESTIONNAIRE}

แบบสงบฤๆมผู้บราขๆสาฉๆอลๆอ

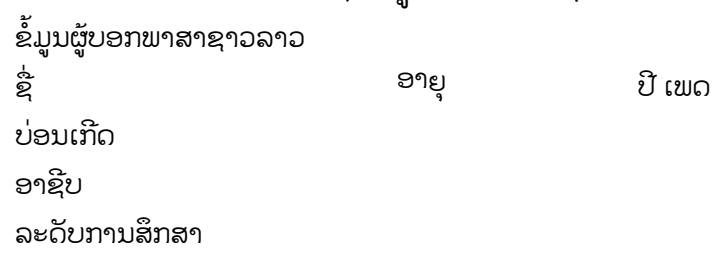

\section{แบบสงบฤจมผู้ขอทขๆสาฉๆอลจอ}

ใข้ ข่าบ ใส่ ละ ถับ ถะ แบบ (1) ทับ ถำ บๆม ข้ ข่าบ ถึล อ่ๆ เปับ

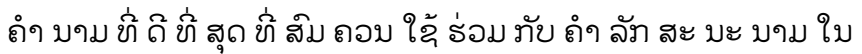
๓า ๓ะ ลๆ ยู่ ลุ่ม บิ้ แล ะ ฤ้ๆ ข่าบ ถึด อ่า เปับ ถำ บขม ใด ขे สิม ถอบ ใฉ้ ธ่อม ทับ ถำ ลัท สะ บะ บขมใบ ลำ ถับ ธง9 ล์ ไป ใข้ ข่าบ ใส่ ละ ถับ ถะ แบบ (2) (3) (4) (5) (6) (7) (8) ๓าม ลำ ถับ

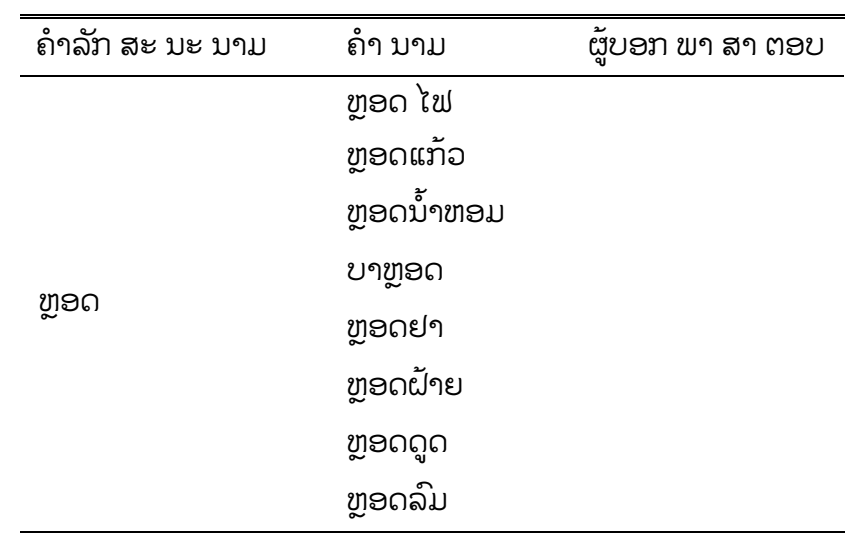




\section{REFERENCES}

[1] W. A. Foley, Anthropological Linguistics: An Introduction, Massachusetts: Blackwell, 1997.

[2] P. Vongvichit, Lao Grammar, Vientiane: Department of Education, 1991, pp. 44-47.

[3] E. Rosch, "Cognitive representation of semantics categories," Journal of Experimental Psychology, 104, vol. 3, pp. 192-233, 1975.

[4] F. Ungerer and H. R. Schmid, An Introduction to Cognitive Linguistics, Oxford: Basil Blackwell, 1996.

[5] G. Lakoff, Women, Fire, and Dangerous Things: What Categories Reveal about the Mind, Chicago, IL: University of Chicago Press, 1987.

[6] M. Viravong, Lao Dictionary, Vientiane: Ministry of Education, 1960 .

[7] D. Bunyavong, The Lao Picture of Dictionary, Vientiane: Phainan, 1995.

[8] K. Nakhasiri and W. Manomaipiboon, Lao-Thai-English Dictionary, Bangkok: Kasetsart University, 2000.

[9] W. Meesathan, Lao-Thai Dictionary, Bangkok: Sahathammik, 2000.
[10] K. Jaturongkachoke, "Cognitive models of the Thai classifier System," in Proc. the Sixth Annual Meeting of the Southeast Asian Linguistics Society, Program for Southeast Asian Studies Tempe.

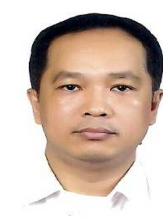

Rattanapraxa Analee was born on April 30, 1968 in Lao People's Democratic Republic. He gained a bachelor degree in English, mass communication at Ramkhamhaeng University and political science in program of international relation and comparative. Sukhothaithammathirat University, and a master of education degree in educational linguistics at Srinakharinwirot University, Bangkok, Thailand.

His current job is an English teacher at Satjawat

Technical School, Thailand.

His research interest is based on cognitive semantics and he is also graduate student in linguistics at Srinakharinwirot university, Bangkok, Thailand. 